\title{
NO ON-GOING GLOBAL FLOODING WITH THE SUN BACK IN THE CENTRE
}

\author{
NILS-AXEL MÖRNER*
}

Abstract

\begin{abstract}
Aristotle's presented the first global model; his model of the planetary system. It was totally wrong. Still, it ruled the world for 1800 years until Copernicus presented an observationally based solution. To leave observational reality behind and to hang on to models and model predictions seem utterly dangerous and basically unscientific. Still, we are today victims of many ruling models. IPCC,s climate-modeling now totally roles the entire world. Still, it is based on very shaky ground including errors, falsifications and misinterpretations. Sea level, for example, is by no means in a rising mode and we can free the world from the condemnation to become flooded in the near future. In about 40 years we will be in a new Solar Minimum and are hence likely to experience a new "Little Ice Age". All this reveals the danger of ruling models, and calls for a return to basic observational facts. Scientific integrity has become vital.
\end{abstract}

Key-words: sea level changes, solar variability, ruling models, observational facts, eustatic variables.

\section{INTRODUCTION}

In true natural science, we have always worked with a basic three-parted scheme, viz. Observation Interpretation - Conclusion.

In case of more unified pictures, we talk about a chain of: Hypothesis - Theory - Paradigm.

This is our scientific base; so it has been and so it ought to be.

In recent years of computer modeling, a new and very dangerous scheme has entered the scientific scene, viz. Idea - Models - "the Truth".

Modeling is a powerful tool assisting us in our search for connections and interacting variables. It should never grow to become a subject of itself. There are bad cases in the past as well as at present (MÖRNER, 2007a).

\section{THE FIRST MODEL EVER PRESENTED}

In the Ionic settlement with the cities of Ephesos, Miletos and Kos (today's SW Turkey), a wonderful, free, natural philosophy flourished. In their understanding of the planetary system, the Sun was where is should be, i.e. in the centre (Fig. 1), no questions about that. With Socrates, Platon and especially Aristotle's things changed. The Earth was placed in the centre and the Sun was proclaimed to move around the Earth.
Aristotle's presented a unified model - the ever first model - of the planetary and celestial mechanics. Everything was explained by movements of the planetary and celestial bodies, along 56 independent circular paths. No one was to object to this masterly "final solution" (later updated by Ptolemaist $\sim 170 \mathrm{BC}$ ).

Some clever persons objected - e.g. Anaxagoras and Aristarkos - but they were rapidly overruled by the master's model.

The Aristotle's-Ptolemaist model was adopted by the Church because the Earth was in the centre, where the Church wanted it to be.

It took about 1800 until reality caught up with the model illusion and Nicolaus Copernicus, in 1543, presented his outstanding observational facts proving that the Sun was in the centre and the planets, including the Earth, were forced to circle around the Sun (Fig. 1). Still, the Church refused to accept the truth. Giordano Bruno was burned to death in 1600, and Galileo Galilei had to deny the facts in 1633 .

\section{THE GLOBAL WARMING SCENARIO}

IPCC's climate - modeling now totally rules the entire world. Still, it is based on very shaky ground including errors, falsifications and misinterpretations. Sea level, for example, is by no means in a rising mode.

* Paleogeophysics \& Geodynamics, Stockholm, Sweden. E-mail: morner@pog.nu 


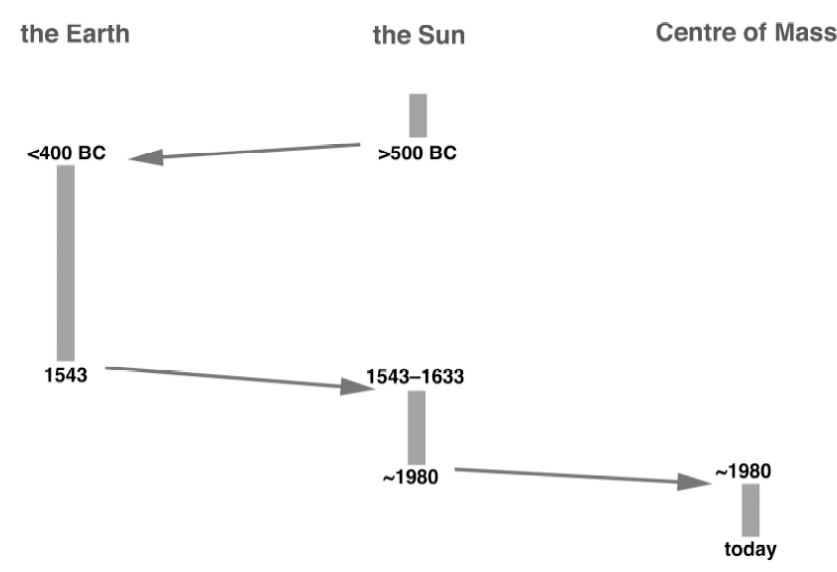

Fig. 1 - Changing opinion of the centre of our planetary system during 2700 years.

It took some 1800 years before the ruling model of Aristotle's could be dismissed by the observationally based results of Copernicus in 1543.
Climate is becoming increasingly warmer we hear almost every day. This is what has become known as "Global Warming".

The idea of IPCC (2001) is that there is a linear relationship between $\mathrm{CO}_{2}$ increase in the atmosphere and global temperature. The fact, however, is that temperature has constantly gone up and down. From 1850 to 1970 , we see an almost linear relationship with Solar variability; not $\mathrm{CO}_{2}$. For the last 30 years, our data sets are so contaminated by personal interpretations and personal choices that it is almost impossible to sort up the mess in reliable and unreliable data.

In the IPCC-scenario, we will face a rapidly increasing temperature in the near future, which will cause an opening of the Arctic Basin (ACIA, 2004). Such a view implies that we neglect the Solar influence (MÖRNER, 2005a).

The fact is that the climatic changes during the last 600 years include cold periods around 1450, 1690 and 1815 that correlate with periods of Solar Minima (the Spörer, Maunder and Dalton Solar Minima). The driving cyclic solar forces can easily be extrapolated into the future (Fig. 2). This would call for a new cold period or "Little Ice Age" to occur at around 2040-2050 in totally contrast to the IPCC-scenario. The Solar influence is simply kept out of the Global Warming concept. It is high time to bring the Sun back into the centre

\section{THE SEA LEVEL NONSENSE}

In the global warming concept, it has been constantly claimed that there will be a causal rise in sea level; a rise that already is in the accelerating mode, in the near future to cause extensive and disastrous flooding of low-lying coastal areas and islands. Is this facts or fiction, what lies behind this idea, and, especially, what do the true international sea level specialists think (INQUA, 2000; MÖRNER, 2004a, 2005a)?

The recording and understanding of past changes in sea level, and its relation to other variables (climate, glacial volume, gravity potential variations, rotational changes, ocean current variability, evaporation/precipitation changes, etc.) is the key to sound estimates of future changes in sea level (MÖRNER, 2004a). The international organizations hosting the true specialists on sea level changes are to be found with the INQUA commission on sea level changes and the IGCP special projects on sea level changes. When I was president of the INQUA Commission on Sea Level Changes and Coastal Evolution, 1999-2003, we paid special attention just to this question; i.e. the proposed rise in sea level and its relation to observational reality. We discussed the issue at five international meetings and by Web-networking (INQUA, 2000). Our best estimate for the next century was $+10 \mathrm{~cm} \pm 10 \mathrm{~cm}$ (INQUA, 2000, MÖRNER, 2004a), later revised by myself to $+5 \mathrm{~cm}$ $\pm 15 \mathrm{~cm}$ (MÖRNER, 2004a, 2005a, 2005b).

It is true that sea level rose in the order of 10-11 $\mathrm{cm}$ from 1850 to 1940 as a function of Solar variability and related changes in global temperature and glacial volume. From 1940 to 1970, it stopped rising, maybe even fell a little. In the last $10-15$ years, we see no true signs of any rise or, especially, accelerating rise (as claimed by IPCC, 2001), only a variability around zero (MÖRNER, 2004a, 2005b). This is illustrated in figure 3 .

From 2000, we have run a special international sea level project in the Maldives (MÖRNER et al., 2004; MÖRNER, 2007b) including six field sessions and numerous radiocarbon dates. Our record for the last 2600 years is given in figure 4 . There are no signs of any on-going sea level rise. It seems all to be a myth. 


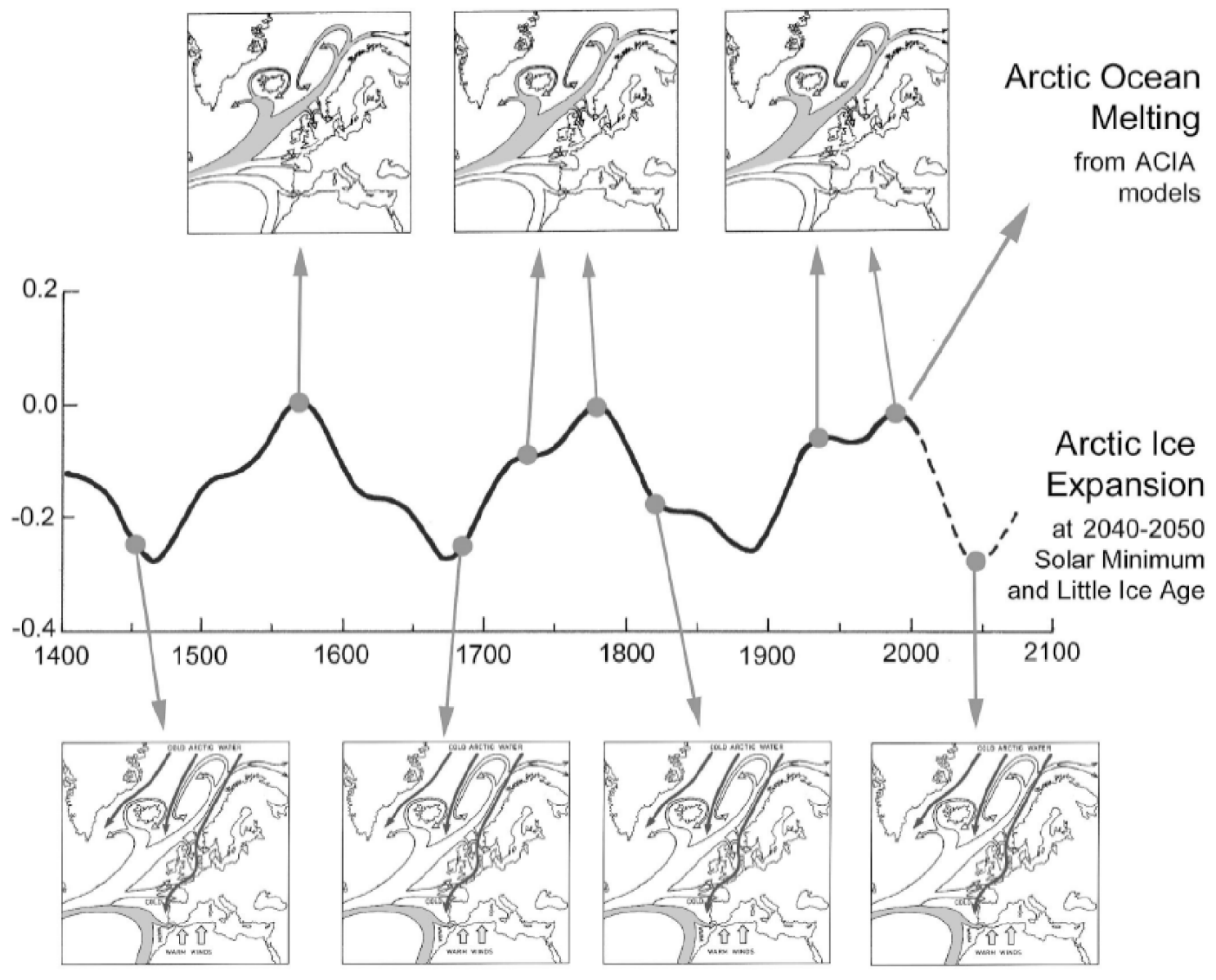

Fig. 2 - The main Solar cycle in the last 600 years with observed ocean circulation pattern at maxima and minima, and the expected extension into the future (from MÖRNER, 2005a). At Solar minima NW Europe, the North Atlantic and the Arctic have experienced cold phases known as "Little Ice Ages". By year 2040-2050, a new Solar Minimum is to be expected, and with a new cold phase over the Arctic and NW Europe.

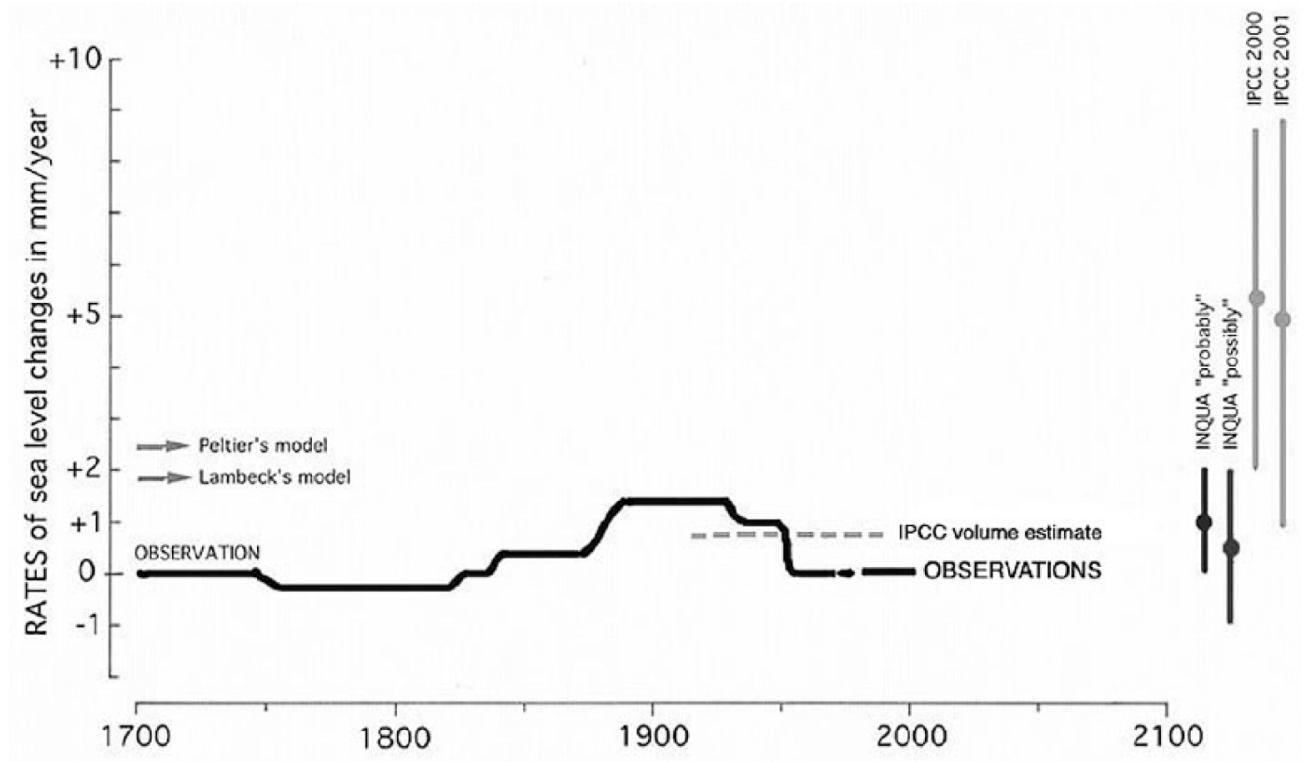

Fig. 3 - Observed sea level changes in the past 300 years and estimated changes by year 2100 (from MÖRNER, 2004a). 
The same result is obtained if one examines other regions; e.g. the records of the famous sites of Tuvalu and Venice and the fundamental new data set from satellite altimetry (MÖRNER, 2004a, 2004b, 2005a, 2005b, 2008).

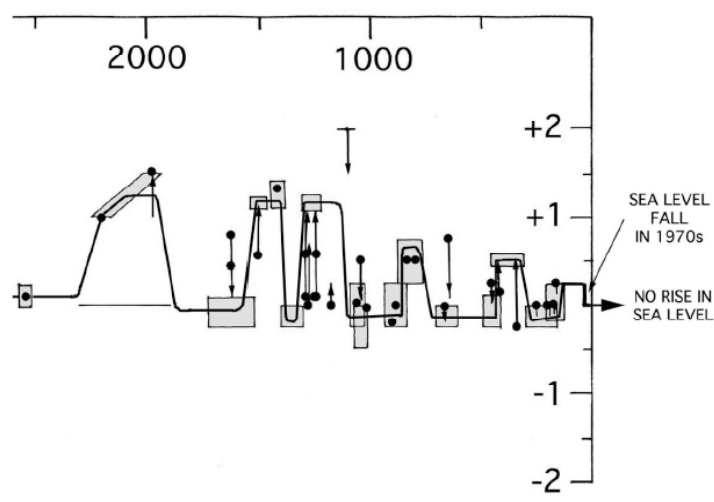

Fig. 4 - The sea level record of the past 2600 years from the Maldives including a significant sea level fall in the 1970s and a lack of signs of any ongoing rise (from MÖRNER, 2007b).

The island of Tuvalu in the Pacific has been claimed to be in the process of being flooded by a rapid global sea level rise. The fact, however, is that the tide-gauge record of the last 25 years does not support this scenario. On the contrary, it shows a quite stable sea level for the last three decades (MÖRNER, 2004b, 2005a, 2007c).

Venice, on the Po delta in northern Italy, represents a slowly subsiding area. Its sea level history is, therefore, dominated by a slowly rising relative sea level factor due to local tectonics and sediment compaction. If global sea level would be in a rising mode, it would have increased the rate of relative sea level rise significantly. This is not the case, however. On the contrary, the relative sea level rise decreased and even stopped in the 1970s (MÖRNER, 2005a, 2007c).

The island of Tegua in the Vanuatu islands in the Pacific was recently (VANUATU, 2005) told to be the first place where people have had to be relocated due to a rising sea level. The background seems rather to be political than truly scientific, however (MÖRNER, 2007c).

Satellite altimetry is a powerful new tool for the recording of global sea level changes. Whilst the first record shows no signs of any rising trend, a later version has a strong rising trend. This trend, however, is imported from subjective analyses of tide-gauge records and does not refer to a true satellite altimetry record (MÖRNER, 2004a, 2005a, 2005b, 2007c, 2008). Whether this should be classified as "misunderstanding" or "falsification", I leave for the readers to decide.

In conclusion; observational data do not support the sea level rise scenario. On the contrary, they seriously contradict it. Therefore, we should free the world from the condemnation of becoming extensively flooded in the near future. Furthermore, in about 40 years, we will be in a new Solar Minimum with related cold period.

\section{SCIENTIFIC PERSPECTIVES}

Scientific progress has always been driven by hard work, sharpness and unbound curiosity. This is our true scientific resource, and it must be the driving forces also in the future. This calls for increased independence of individual scientists and scientific organizations. Ruling models must not take over as guiding tool. Even ruling scientific paradigm must be questioned and tested. In view of this, I predict a total collapse of the global warming and sea level rise scenarios in the near future when observations have caught up with modeling.

\section{APPENDix: AdDitional GENERAL NOTE ON SEA LeVel CHANGeS}

The shoreline, or coastal mean sea level, is the point where the ocean level intersects the land level. The shoreline is ever changing; in micro-scale or in macro-scale depending upon operating causation mechanisms. The displacement of the shoreline is a function of a delicate balance of numerous parameters; viz. those changing the coastal dynamics, those changing the ocean level and those changing the land level. It has taken a long time to understand and define this interaction of multiple different variables (MÖRNER, 1976, 1986, 1996a).

The word "eustasy" has, by tradition, been used to denote changes in the oceanic level as opposed to changes in the crustal level. Originally, it was assumed that changes in the ocean level were identical all over the globe. Hence, eustasy was defined as "simultaneous changes in global sea level" (FAIRBRIDGE, 1961). Later, it was understood that changes in the ocean level are not simultaneous and similar over the globe, but differential and sometimes even opposed (MÖRNER, 1976, 2000). Therefore, Mörner (1986) proposed a redefinition of the term "eustasy" to denote "changes in ocean level (regardless of causation)".

Figure 5 illustrates the five main eustatic factors: (1) glacial eustasy, (2) tectono-eustasy, (3) geoidal eustasy, (4) dynamic changes, and (5) rotation eustasy. Each parameter may be quantified as to rate, amount and time-application (MÖRNER, 1996b). 

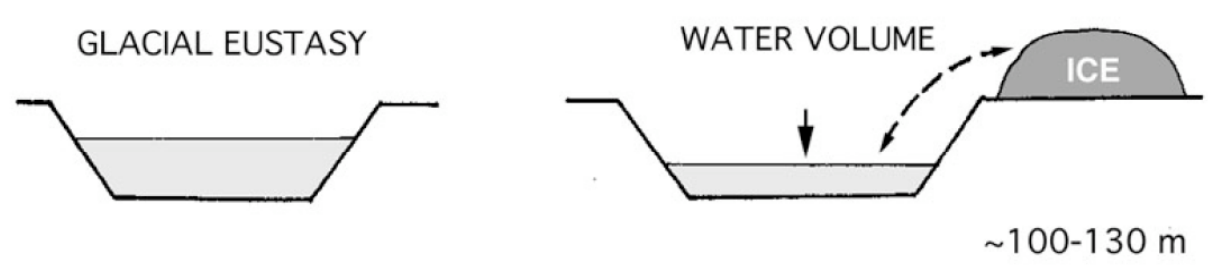

TECTONO EUSTASY

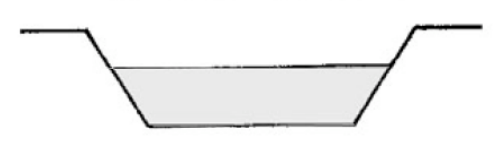

GEOIDAL EUSTASY

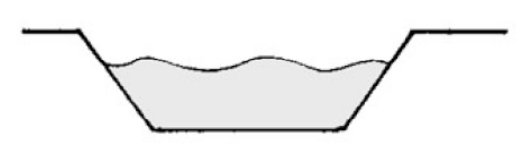

DYNAMIC CHANGES
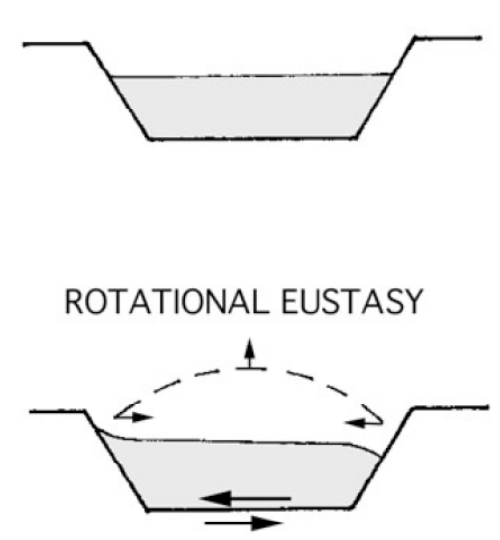

21.385 m Pole/Equator plane $1 \mathrm{~m}$ per $15 \mathrm{~ms}$ rotation

\section{BASIN VOLUME}

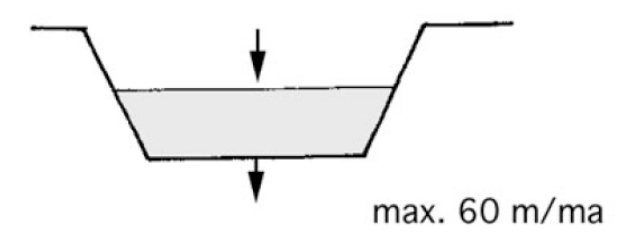

WATER DISTRIBUTION

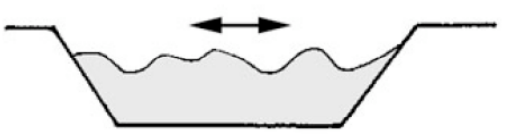

$180 \mathrm{~m}$ relief

(30 m last 20 ka, 5-10 m last 8 ka)

SEA SURFACE TOPOGRAPHY

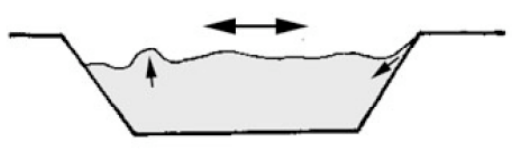

$2 \mathrm{~m}$ in low harmonics

(Gulf Stream 5 m, El Niño $0.3 \mathrm{~m}$ )

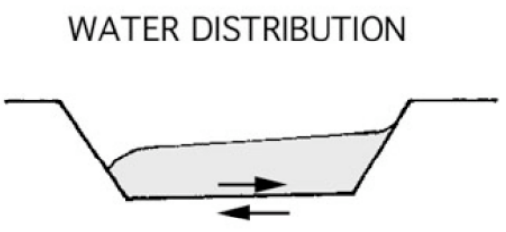

Decadal 1.0-0.1 m changes ("Super-ENSO-events")

Fig. 5 - Main eustatic variables with some quantification added. The glacial eustasy in the Quaternary has a sea level range of about 100-130 m. Tectono - eustasy is a very slow process, of negligible significance in the Holocene, with a maximum rate of $0.06 \mathrm{~mm} / \mathrm{year}$.

The geoid has a maximum present topographic relief of $180 \mathrm{~m}$. The changes in the geoid relief seem to have amounted to about $+30 \mathrm{~m}$ at $20 \mathrm{ka}$ and some $5-10$ in the last 8000 years. The sea surface topography has, in the low harmonics, a relief of about $2 \mathrm{~m}$. At major currents, like the Gulf Stream, it may amount to a few to $5 \mathrm{~m}$. The El Niño signal is typically $+0.3 \mathrm{~m}$. Rotation causes a very large bulge difference between the polar and equatorial plane of $21,385 \mathrm{~m}$. The relation between spin rate and sea level height is about $15 \mathrm{~ms}$ spin rate to $1 \mathrm{~m}$ sea level.

Decadal changes in the Earth's rate of rotation have a potential to redistribute oceanic water masses rising, and lowering regional sea level in to order of 1.0 to $0.1 \mathrm{~m}$ (known as "Super- ENSO events"). 


\subsection{THE GLACIAL-INTERGLACIAL SEA LEVEL CYCLE}

The mean glacial eustatic changes in sea level include a Last Interglacial level in the order of some metres above the present sea level, a Last Glaciation Maximum (LGM) at about -120-130 m, and a Holocene sea level at $\sim 0 \mathrm{~m}$ reached some 5000-6000 ${ }^{14} \mathrm{C}$-years BP. These levels represent some sort of mean values. Often, however, other positions are recorded. The reasons for this may vary. Usually, it is a function of differential crustal movements. The rise from the $20 \mathrm{ka}$ LGM low to the present Holocene level is often approximated by a smoothly rising curve (FAIRBANKS, 1989) although the predominant number of detailed field investigations records an episodic rise (CARTER et al., 1986; FLETCHER \& SHERMAN, 1995; COLLINAGIRARD, 2002; MÖRNER et al., 2003).

It has been proposed that global sea level can be both reconstructed and predicted by means of a geophysical global loading model (PELTIER, 1998). The basic assumption of these models is that the loading and de-loading by the waxing and waning ice caps of the Ice Ages generate a global isostatic adjustment of coasts and sea-floors all around globe. This is only possible, however, if the Earth has a linear viscosity profile in the mantle. The reality and efficiency of the model can be easily tested in (1) the near-field, and (2) in the far-field with respect to the ice caps. If actual observational data are used, the test fails in the near-field (at least in Fennoscandia) and in the far field (the Indian Ocean and the Pacific) as further discussed in Mörner (2005).

\subsection{THE LAST 5000 YEARS}

Up to 5000-6000 C14-years BP, the sea level changes were dominated by a general rise of glacial eustatic origin. After some 5000 C14-years BP (when the glacial eustatic factor had ceased), the situation changed to a dominance of redistribution of the water masses over the globe (MÖRNER, 1996a). The main driving forces for this redistribution of water over the globe seem to be the interchange of angular momentum between the solid Earth and the hydrosphere (MÖRNER, 1995) driving and controlling ocean surface circulation in some sort of Super-ENSO/Super-non-ENSO variability (rotational eustasy in Fig. 5).

\subsection{THE PRESENT}

I have recently discussed the present general sea level trend with respect to past records and future expectations (MÖRNER, 2003, 2004a). It will not be repeated here again. For the last decade, satellite altimetry has become an important new tool. In my previous papers (op. cit.), I showed the observational raw-data for the period 1992-2000. The extension up to 2003 can be found on Internet (NASA/CNES), but with a significant change; now the original data set has been "corrected" so that it has assumed a tilting trend. When the new curve is calibrated back to its original ("uncorrected") observational values, a curve is given that lack signs of any rising trend (MÖRNER, 2005b, 2008; Fig. 5). A number of ENSO-events are recorded superimposed on a mean trend around zero (MÖRNER, 2004a, 2005b). This implies a total lack of signs of an on-going sea level rise (MÖRNER, 2004a, 2007c; MÖRNER et al., 2004), and certainly not of any recent sea level acceleration, as claimed in the IPCC scenario (IPCC, 2001; cf. IGBP, 1990, 1992).

\section{ACKNOWLEDGEMENTS}

I acknowledge, with the greatest pleasure, the wonderful symposium in Porto, Portugal, arranged by Maria Assunção Araújo on September 19, and the excellent field days along the coast before and after the meeting. So much to see, so much to learn, and so much to enjoy.

\section{REFERENCES}

ACIA (2004). Impact of a Warm Arctic: Arctic Climate Impact Assessment. ACIA Overview Report. Cambridge Univ. Press. Also: http://amap.no/acia/

CARTER, R.M., CARTER, L. \& JOHNSON, D.P. (1986). Submergent shorelines in the SW Pacific: evidence for an episodic post-glacial transgression, Sedimentology, 33, pp. 629-649.

COLLINA-GIRARD，J. (2002). Underwater mapping of Late Quaternary submerged shorelines in the Western Mediterranean Sea and the Caribbean Sea. Quaternary International, 92 , pp. 63-72.

FAIRBANKS, R.G. (1989). A 17 kyr glacio-eustatic sea level record: influence of glacial melting rates on the Younger Dryas event and deep-ocean circulation. Nature, 342, pp. 637-642.

FAIRBRIDGE, R.W. (1961). Eustatic changes in sea level. Physics \& Chemistry of the Earth, 4, pp. 99-185.

Fletcher, C.H. \& SHERMAN, C.E. (1995). Submerged Shorelines on O'ahu, Hawaï'i: Archives of episodic transgression during the deglaciation. Journal of Coastal Research, Sp. Issue17, pp. 141-152. 
IGBP (1990). The International Geosphere-Biosphere Programme. A study of Global Change. IGBP Report 12.

IGBP (1992). Global Change. Reducing uncertainties. IGBP Publications.

INQUA (2000). The Commission on Sea Level Changes and Coastal Evolution (1999-2003), Sea level changes, News \& Views, The Maldives Project, <www.pog.su.se/sea>, accessed January.

IPCC (2001). Climate Change. Cambridge Univ. Press.

MÖRNER, N.-A. (1976). Eustasy and geoid changes. Journal of Geology, 84, pp. 123-151.

MÖRNER, N.-A. (1986). The concept of eustasy. A redefinition. Journal of Coastal Research, S.I. 1, pp. 49-52.

MÖRNER, N.-A. (1995). Earth rotation, ocean circulation and paleoclimate. GeoJournal, 37, pp. 419-430.

MÖRNER, N.-A. (1996a). Sea level variability. Z. Geomorph. N.F., Suppl.-Bd. 102, pp. 223-232.

MÖRNER, N.-A. (1996b). Rapid changes in coastal sea level. Journal of Coastal Research, 12, pp. 797-800.

MÖRNER, N.-A. (2000). Sea level changes and coastal dynamics in the Indian Ocean. Integrated Coastal Zone Management, 1, pp. 17-20.

MÖRner, N.-A. (2003). Sea level changes in the Past, at Present and in the Near-Future. Global Aspects. Observations versus Modells. IGCP - 437 Puglia Conference, GI ${ }^{2} \mathrm{~S}$ Coast, Research Publication, 4, pp. 5-9.

MÖRNER, N.-A. (2004a). Estimating future sea level changes. Global Planetary Change, 40, pp. 49-54.

MÖRNER, N.-A. (2004b). Sea level changes: Are low-lying islands and coastal areas under threat? in The impacts of climate change. An appraisal for the future, pp. 29-35. International Policy Press.
MÖRNER, N.-A. (2005a). Facts and Fiction about Sea Level Changes: may low-lying islands and coastal areas be freed from the condemnation to become flooded in the near future, House of Lords, Economic Affairs Committee, Report, pp. 1-6.

MÖRNER, N.-A. (2005b). Sea level changes and crustal movements with special aspects on the Mediterranean. $Z$. Geomorph. N.F., Suppl. vol. 137, pp. 91-102.

MÖRNER, N.-A. (2007a). The danger of ruling models in a world of natural changes and shifts, in V. Burdyuzha (ed.) The Future of Life and the Future of Our Civilization, Springer, pp.105-114.

MÖRNER, N.-A. (2007b). Sea level changes and tsunamis, environmental stress and migration overseas. Internationales Asienforum, 38, pp. 353-374.

MÖRNER, N.-A. (2007c). The Greatest Lie Ever Told. ISBN-97891-977047-0-0, P\&G-print (C MÖRNER).

MÖRNER, N.-A. (2008). Comment on comment. Global Planetary Change, 62, pp. 219-220.

Mörner, N.-A., LABorel, J., TOOLEy, M., DAwson, S., Allison, W., ISLAM, M.S., LABOREL, F., COllina, J. \& RuFIN, C. (2003). Sea level changes: the Maldives Project. Freed from condemnation to become flooded (MÖRNER \& Maldives Project Members). GI ${ }^{2} \mathrm{~S}$ Coast, Research Publication, 4, pp. 175-176.

Mörner, N.-A., Tooley, M. \& Possnert, G. (2004). New perspectives for the future of the Maldives. Global Planetary Change, 40, pp. 177-182.

Peltier, W.R. (1998). Postglacial variations in the level of the sea: implications for climate dynamics and solid-earth geophysics. Reviews of Geophysics, 36, pp. 603-689.

VANUATU (2005). Vanuatu Village may be first climatic change "refugees".

http://www.news.vu/en/news/environment/051221Vanuatu-Villagers-May-Be--First-Climate-ChangeRefugees.shtml 